\author{
Monika Karbowska \\ Uniwersytet w Białymstoku \\ E-MAIL: karbowska.monika@interia.pl
}

\title{
Młode i wściekłe. W poszukiwaniu źródeł agresji nastolatek
}

\section{STRESZCZENIE}

Od 20 lat obserwuje się znaczący wzrost zachowań przemocowych, których dopuszczają się nastoletnie dziewczęta. W artykule omówiono znaczenie okresu dojrzewania, wpływu grupy rówieśniczej, środowiska rodzinnego oraz szkoły w generowaniu agresji. Przedstawiono różnice w motywach i formach zachowań agresywnych dziewcząt i chłopców oraz wybrane koncepcje wyjaśniające przyczyny agresji kobiet.

SŁOWA KLUCZOWE: nastolatki, agresja, wychowanie, edukacja, kultura

Kiedy media opisują przypadki przemocy w relacjach rówieśniczych, której sprawcami są chłopcy, nie podają płci sprawcy. Stwierdza się, że mamy do czynienia $\mathrm{z}$ agresją nastolatków lub z problemem przemocy wśród młodzieży. Jednak gdy agresji dopuszczają się dziewczyny, zderzenie zakorzenionego w społecznej świadomości stereotypu słabej płci: delikatnej, wrażliwej, bezbronnej, z aktami brutalnej przemocy w wykonaniu nastolatek szokuje i zmusza do refleksji. Jak wynika $z$ danych Policji na przestrzeni lat 1999-2010 drastycznie wzrosła liczba młodych kobiet podejrzanych o popełnienie przestępstw z użyciem przemocy:

- o 169\% wzrosła liczba dziewczyn do 16. roku życia podejrzanych o bójki i pobicia, podczas gdy wzrost liczby chłopców w tej kategorii wyniósł $55 \%$;

- o ponad $176 \%$ wzrosła liczba dziewczyn do 16 . roku życia - podejrzanych o niszczenie i uszkodzenie mienia, podczas gdy wzrost liczby chłopców w tej kategorii wyniósł 38,3\%;

- o 61\% wzrosła liczba dziewczyn do 16. roku życia - podejrzanych o spowodowanie uszczerbku na zdrowiu, podczas gdy wzrost liczby chłopców w tej kategorii wyniósł 20\%.

Podobne tendencje można zaobserwować w kategorii wiekowej 17-20 lat. Wzrosła liczba podejrzanych kobiet o spowodowanie uszczerbku na zdrowiu o 16\%, podczas gdy liczba mężczyzn zmalała o 14,9\%. Podobna sytuacja jest w przypadku bójek i pobić - wzrost liczby kobiet o 34,5\%, wzrost liczby mężczyzn tylko o o,3\% (Piotrowska i Synakiewicz, 2010). 
Mimo że w ogólnym zestawieniu danych liczbowych dotyczących aktów przemocy to płeć męska ma zdecydowaną przewagę (dziewczęta do 16. roku życia stanowią 12,7\% sprawców, zaś chłopcy - 87,3\%; w przypadku osób powyżej 17 . roku życia mężczyźni stanowią 85,7\% sprawców) (Piotrowska i Synakiewicz 2010), narastający charakter zjawiska każe zastanowić się nad jego osobowościowymi i społeczno-kulturowymi uwarunkowaniami. Jakie są przyczyny gwałtownego wzrostu zachowań agresywnych, których sprawcami są dziewczęta? Próby wyjaśnienia tego fenomenu "tradycyjnym” postrzeganiem agresji jako reakcji spowodowanej zmianami hormonalnymi okresu dojrzewania, wpływem środowiska rodzinnego lub szkolnego, ewentualnie grupy rówieśniczej, są niewystarczające, gdyż tylko częściowo tłumaczą mechanizmy tego zjawiska, które ze względu na skalę i zasięg staje się poważnym problemem społecznym. Warto jednak prześledzić potencjalne determinanty agresji, gdyż od właściwej diagnozy przyczyn zależy skuteczność stosowanych strategii zaradczych.

\section{Okres dojrzewania jako czynnik ryzyka zachowań agresywnych}

Przemoc wśród nastolatków, mimo bezpośrednich uciążliwości, a nawet dotkliwych negatywnych skutków dla samej jednostki i jej najbliższego otoczenia, nie stanowiłaby aż tak poważnego problemu społecznego, gdyby zamykała się w ograniczonym okresie rozwojowym i nie rozciągała się na kolejne etapy rozwoju, a nawet całe życie człowieka (Urban, 2012, s. 56-57).

Okres adolescencji określany jest jako „okres burzy i naporu” (Żebrowska, 1994, s. 661). Wzmożona wrażliwość, labilność emocjonalna jest traktowana jako charakterystyczna cecha dorastającej osoby. Doświadczenia emocjonalne odgrywają u nastolatków szczególnie ważną rolę. Przyczyny i źródła wzmożonej emocjonalności dorastających tkwią zarówno w sferze fizjologicznej (funkcje hormonalne organizmu), jak i w sferze doświadczeń społecznych (aktywny udział w życiu społecznym). Jako typową cechę życia emocjonalnego dorastającej młodzieży wyróżnia się intensywność doznań. Przeżyciom towarzyszy wysoki poziom napięcia: smutek odczuwany jest głęboko i bardzo często ma charakter „tragedii”, radość osiąga szczyty uniesienia. Inną powszechną cechą jest łatwość oscylacji między nastrojami krańcowymi: dorastający w jednej chwili przerzucają się od radości do smutku, od entuzjazmu do zniechęcenia, od nadziei do rozpaczy. Wiąże się z tym szczególna, uwarunkowana emocjonalnie, chwiejność w sferze przekonań. Ta sama osoba ma nierzadko diametralnie przeciwne skłonności i upodobania (s. 661).

Charakterystyczne dla tego okresu stopniowe opanowywanie reakcji emocjonalnych i kształtowanie się uczuć wyższych zależy od rozwoju procesów intelektualnych, a przede wszystkim od wpływu czynników społeczno- 
-kulturowych. Wzorce i normy kulturowe, które dopiero na tym etapie adolescenci potrafią przyswoić sobie ze zrozumieniem, bardziej świadomie i krytycznie, wywołują u nich silne reakcje emocjonalne. Kształtowaniu się postaw, przekonań i opinii towarzyszą wahania moralne i rozterki intelektualne. Kształtowanie się hierarchii wartości i ocen rzutuje na obraz świata oraz na obraz samego siebie, stanowi również podłoże powstawania nowych jakości uczuciowych. Uczucia, afekty, nastroje i namiętności przeżywane przez młodzież nie są zjawiskami wyizolowanymi z całokształtu jej życia psychicznego, ale stanowią jego integralną część, włączoną w proces rozwoju osobowości, w wielokierunkową działalność w różnych środowiskach. Gniew jest wyjątkowo często przeżywanym stanem uczuciowym dorastających. Stanowi typową $\mathrm{w}$ tej grupie reakcję na frustrację. Pod jego wpływem młodzi często reagują agresją. Młodzież dorastająca wyraża gniew w formach zróżnicowanych i pośrednich, takich jak: krytykowanie, ponure milczenie, sarkazm, przekleństwa. Dorastający ludzie popadają w zły humor zazwyczaj, gdy ich plany zostają zmienione pod wpływem osób dorosłych, kiedy mają uczucie, że ich prawa są ograniczane lub wtedy, gdy są przekonani, że dorośli nie chcą ich zrozumieć (Turner i Helms, 2006, s. 89-90).

Uważa się, że typową przyczyną gniewu u chłopców jest poczucie własnej nieudolności lub nieumiejętności, brak sukcesu w podjętym działaniu oraz porażki odniesione we współzawodnictwie. Chłopców, bardziej niż dziewczęta, złoszczą różne formy zachowań agresywnych ze strony rodzeństwa lub kolegów, zarówno fizyczne, jak i słowne, np. dokuczanie, przezywanie, wyśmiewanie. Dziewczęta natomiast irytuje niewłaściwe zachowanie się chłopców, np. zaczepki, chuligaństwo, głupie żarty, psoty, docinki (Obuchowski, 2002, s. 77-78). Wydaje się jednak, że obecnie mamy do czynienia $\mathrm{z}$ postępującym równouprawnieniem również w tej sferze. Można bowiem zaobserwować znaczący wzrost liczby wrażliwych chłopców oraz ambitnych, skłonnych do rywalizacji dziewcząt.

W okresie dorastania szczególnego znaczenia nabiera włączanie się w życie społeczne. Relacje osobowe wśród nastolatków stają się intensywniejsze nie tylko dlatego, że dla dorastających ogromne znaczenie ma uzyskanie akceptacji rówieśników, ale też z powodu odczuwania przez nich potrzeby dzielenia się swymi nowymi przeżyciami, doświadczeniem i uczuciami. W okresie tym rówieśnicy i grupy rówieśnicze oferują oparcie i poczucie przynależności tym, którzy usiłują zapewnić sobie niezależność od rodziny i osobistą autonomię (Misiewicz, 2007, s. 44-45). Mogą jednak generować specyficzne problemy, np. związane z wykluczeniem, walką o pozycję, agresją wewnątrz grupy czy konfliktem między grupami, jak to się dzieje w wypadku młodych kibiców. 


\section{Dorośli wobec przemocy nastolatków}

Wyniki badań przeprowadzonych przez A. Wojnarowską (2008) wśród uczniów szkół gimnazjalnych pokazują, że w okresie adolescencji obserwuje się podwyższony poziom agresywności ogólnej oraz w zakresie napastliwości słownej, negatywizmu, przy jednoczesnym niskim poczuciu winy. Niepokojące jest przyzwolenie dorosłych na tego typu zachowania nastolatków, co ujawnia się na przykład w kojarzeniu napastliwości z dobrym uspołecznieniem. Ponadto wyniki badań wskazują, że płeć nie jest zmienną modyfikującą poziom agresywności oraz kompetencji społecznej. Obserwowana na przestrzeni ostatnich lat rewolucja obyczajowa spowodowała zmiany w zachowaniu dziewcząt wyrażające się w większej niż kilkanaście lat temu agresywności, cynizmie oraz udziale w przestępstwach (Wojnarska, 2008, s. 284).

Wyniki badań potwierdzają także istnienie korelacji między zachowaniem rodziców a poziomem agresji $u$ ich dzieci. Odrzucenie przez ojca, w percepcji nastolatków, było bardzo mocno związane z różnymi formami agresywnych zachowań:

[Z]achowanie rodziców, zwłaszcza ojca, może być predyktorem tych cech osobowości, które związane są z fizyczną agresją u chłopców i słowną agresją u dziewcząt (Kulik, Grądziel i Pieńkoś, 2016, s. 215).

Społeczna tolerancja dla zachowań o charakterze przemocy to aspekt, który nadal różnicuje płeć żeńską od męskiej. Już od najmłodszych lat małe dziecko otrzymuje ze strony rodziców i innych bliskich osób ze swojego otoczenia różne sygnały zwrotne na temat własnego zachowania. Badania w tym zakresie pokazują, że rodzice bardziej tolerują agresję u chłopców aniżeli u dziewczynek. Społeczne nagradzanie chłopców za ich agresywne zachowania zwiększa ryzyko takich zachowań w przyszłości i jednocześnie zmniejsza refleksyjność chłopców w odniesieniu do aktów agresji (Samujło, 1998, s. 44).

Inne - poza modelowaniem - przyczyny przemocy, które mają swoje źródło w środowisku rodzinnym, są związane najczęściej z niezaspokajaniem podstawowych potrzeb dziecka, takich jak: potrzeba miłości, bezpieczeństwa, autonomii i akceptacji, a także ekspansji. Zakłócenie relacji między rodzicami a dzieckiem może wpływać na kształtowanie się zachowań niepożądanych, w tym także tych o charakterze przemocy. Nastolatki, które dorastają $\mathrm{w}$ rodzinie o niedemokratycznym stylu wychowania, gdzie rodzice nie uczą konstruktywnych sposobów rozwiązywania konfliktów, mogą mieć większą skłonność do przejawiania zachowań agresywnych, także w dorosłym życiu. 


\section{Szkoła jako środowisko sprzyjające przemocy}

W środowisku szkolnym uczniowie spędzają znaczną część swojego życia i z tego też powodu rola szkoły w kształtowaniu osobowości młodego człowieka jest bardzo istotna. W tym miejscu należy zaznaczyć, że młodzież w szkole nie tylko uczy się reguł i zachowań akceptowanych społecznie, ale także zachowań niepożądanych i nieakceptowanych przez społeczeństwo. Szkoła jest środowiskiem, w którym można zaobserwować liczne przejawy przemocy rówieśniczej, ale także w relacjach nauczyciel - uczeń, przy czym w ostatnich latach role sprawcy i ofiary w ramach tej relacji wcale nie są oczywiste. Działania szkoły wobec zjawiska przemocy nie zawsze i nie wszędzie są wystarczające. Zmęczeni nauczyciele i uczniowie, będący ofiarami przemocy, przyjmują często postawę rezygnacyjną, uważając, że w tej sprawie nic nie da się zrobić. Szkoła wywołuje u wielu uczniów negatywne emocje - opiera się na przymusie, nie daje możliwości wyboru, a wręcz ogranicza w przestrzeni, w aktywności ruchowej, werbalnej, a niekiedy także intelektualnej. Nauka do 18 roku życia jest obowiązkiem, co powoduje, że wielu uczniów deklaruje negatywne emocje i postawy wobec szkoły i wymagań określonych społeczną rolą ucznia, a to często jest powodem frustracji, która prowokuje młodych ludzi do zachowań nieakceptowanych społecznie. Stąd niektórzy twierdzą, że środowisko szkolne w sposób naturalny jest środowiskiem agresogennym (Poraj, 2006, s. 92).

Szkołę jako instytucję wychowującą i nauczającą od lat poddaje się gruntownej krytyce, ponieważ realizuje na swoim terenie, w sformalizowanym systemie, „ukryty program” dominacji i władzy. Trudno sobie wyobrazić, żeby w takich okolicznościach tworzyły się optymalne warunki dla wszechstronnego rozwoju uczniów. W wielu obszarach funkcjonowania szkoły można wyróżnić elementy, które zakłócają proces kształtowania młodych ludzi. Przede wszystkim szkoła charakteryzuje się przerostem funkcji dydaktycznych nad wychowawczymi. Jest ona skoncentrowana na osiągnięciach poznawczych uczniów, a pomija lub ignoruje kształtowanie woli i charakteru. Wiedza często jest abstrakcyjna, przekazywana za pomocą tradycyjnych, werbalnych metod nauczania. Ponadto wielu psychologów i pedagogów zwraca uwagę na to, że szkoła blokuje spontaniczną aktywność twórczą dzieci i młodzieży. Uczniowie żyją w wyizolowanym świecie nauki, daleko od aktualnych wydarzeń społeczno-politycznych, ekonomicznych, kulturalnych (Poraj, 2006, s. 92).

G. Hüther i U. Hauser są zdania, że we współczesnych szkołach przekazywana $\mathrm{w}$ nich wiedza i nabywane w procesie edukacji doświadczenia nie wystarczają już dziś do tego, by odpowiednio przygotować młodych ludzi do 
wielu wyzwań, jakim będą musieli sprostać jako dorośli. Dlatego tak ważne jest, aby szkoła nie tłumiła w uczniach istotnych cech potrzebnych do rozwiązywania zadań przyszłości, do których według tych autorów należy przede wszystkim: kreatywność, odwaga, ufność, upór, poczucie odpowiedzialności, a także świadomość społeczna (Hüther i Hauser, 2014, s. 17). Wymienione cechy osobowości wydają się także nie mniej istotne z punktu widzenia zapobiegania zachowaniom agresywnym w środowisku szkolnym.

Ponadto duży problem w polskich szkołach stanowi także sposób oceniania zachowania i wiedzy uczniów. Z racji wymogów programowych i braku miejsca na oddziaływania wychowawcze oceny stają się podstawowym celem nauczania. Także nauczyciel podlega ocenie na podstawie wyników osiąganych przez jego uczniów. Oceny wystawiane uczniom i nauczycielom często są nieobiektywne i wywołują sporo napięć. Często też towarzyszy im tzw. ocena utajona, wyrażona mimiką twarzy, tonem głosu czy gestem nauczyciela (albo hospitującego dyrektora). System oceniania skoncentrowany na mierzalnych wynikach rodzi silne poczucie krzywdy i wywołuje frustrację, która często prowadzi do zachowań agresywnych (Poraj, 2006, s. 93).

Przemocy w szkole sprzyjają zbyt liczne klasy, które są przyczyną anonimowości uczniów i uprzedmiotowienia relacji z nauczycielami. Uczniowie są często przeciążeni obowiązkami szkolnymi. Zmusza się ich do wielogodzinnego siedzenia $\mathrm{w}$ ławkach, $\mathrm{w}$ ciszy i bezruchu. Jeśli nie stosują się do wymagań, podlegają karze. Niebagatelne znaczenie ma też nagromadzenie tak dużej liczby osób na ograniczonej przestrzeni. Do szkoły przychodzą dzieci o różnym temperamencie, $\mathrm{z}$ różnymi nawykami, cechami osobowości, postawami i oczekiwaniami. Niektórzy uczniowie chcą rywalizować, rządzić, ścigają się o pozycję w grupie, chcą zaimponować innym, czasami kompensując w ten sposób swoje braki i ograniczenia. Wszystkie te okoliczności mogą rodzić konflikty i prowadzić do agresji. Należy jeszcze dodać, że to często w szkole dzieci i młodzież mają do czynienia po raz pierwszy z alkoholem, nikotyną oraz z innymi substancjami psychoaktywnymi, niekiedy po raz pierwszy doświadczają bezpośredniej przemocy i są świadkami agresywnych zachowań. Tworzy to obraz współczesnej szkoły, która przestała spełniać funkcję wychowawczą, a stała się miejscem demoralizacji uczniów (Poraj, 2006, s. 91).

Szkoła to bogactwo relacji interpersonalnych w rozmaitych konfiguracjach, bowiem w środowisku szkolnym mamy do czynienia nie tylko z relacjami rówieśniczymi i relacjami między uczniami i nauczycielami, ale także między samymi nauczycielami, między nauczycielami a dyrektorem, a także pomiędzy nauczycielami a rodzicami. Badacze środowiska szkolnego wskazują, że 
atmosferę szkoły charakteryzuje przede wszystkim napięcie, zależność oraz dystans emocjonalny (Poraj, 2006, s. 92). Uczniowie niejednokrotnie nie postrzegają nauczycieli jako wychowawców, ale jako osoby represjonujące. Zamiast zbudować bliskie relacje, gwarantujące sukces osobistego rozwoju uczniom i satysfakcję nauczycielom, tworzy się barykadę, a po jej przeciwnych stronach - jako wrogowie - ustawiają się uczniowie i nauczyciele (Poraj, 2006, s. 95). Społeczne kampanie informacyjne dotyczące przemocy wobec dzieci utrwaliły ten podział. Można zaobserwować sytuacje, w których próby zdyscyplinowania uczniów są nazywane przemocą. Coraz częściej to uczniowie pozwalają sobie na akty agresji wobec nauczycieli, groźby, niszczenie mienia, przemoc werbalną i fizyczną. Niekiedy akty te są filmowane i umieszczane w Internecie. Szkoły ustalają strategie postępowania w sytuacji agresji ze strony ucznia wobec nauczyciela (Winczewska, 2019).

Formacja szkolna napotyka na wiele przeszkód: trudności w nauce, różnego rodzaju zaburzenia wynikające $\mathrm{z}$ nieharmonijnego rozwoju, nadpobudliwość psychoruchowa czy zaburzenia zachowania. Nauczycielom trudno sobie z nimi poradzić, zwłaszcza jeśli ich klasa jest bardzo liczna. Ponadto rola rodziców jako tradycyjnych sojuszników nauczycieli w procesie socjalizacji młodzieży uległa zmianie. Często oczekują oni, że szkoła naprawi ich własne niepowodzenia wychowawcze lub obarczają szkołę całkowitą odpowiedzialnością za formację społeczną dzieci, co stanowi duże obciążenie emocjonalne i źródło stresu dla nauczycieli (Poraj, 2006, s. 95).

\section{Agresja chłopców i dziewcząt - różnice i podobieństwa. Ujęcie tradycyjne}

Rola tożsamości płciowej w regulacji zachowania jednostki, zarówno pozytywna jak i negatywna, doczekała się w literaturze przedmiotu wielu różnych opracowań. Wśród nich należy wymienić przede wszystkim prace poświęcone związkom zachodzącym pomiędzy tradycyjnie pełnioną rolą mężczyzny a zachowaniem agresywnym. $Z$ tych prac wynika, iż „wpływ męskiej roli płciowej na postawy i zachowania człowieka zaznacza się już we wczesnym okresie rozwoju. Zachowania dzieci wydają się znajdować pod szczególnie silnym wpływem norm regulujących role płciowe, których przekroczenie niekiedy spotyka się z ostrzejszymi sankcjami aniżeli przekroczenie norm moralnych" (Radochoński, 2008, s. 247).

Powszechnie znane stereotypy na temat płci żeńskiej charakteryzują ją jako troskliwą, opiekuńczą, delikatną w stosunku do innych ludzi, tworzącą emocjonalny fundament rodziny. Natomiast dla płci męskiej przeznaczona jest inna funkcja: nadzorowanie rodziny i zapewnianie jej materialnego 
dobrobytu, dlatego cechy, jakimi powinni się odznaczać mężczyźni, to: waleczność, umiejętność sprawowania kontroli, zdobywanie władzy oraz skłonność do rywalizacji (Napierała, 2012, s. 78).

Badania (Levy, 1995) pokazały, że dzieci już w wieku przedszkolnym prezentują dość sztywne postawy wobec przestrzegania zasad regulujących zachowanie zgodne z płcią, które na późniejszym etapie rozwoju człowieka ulegają pewnemu uelastycznieniu. Jednakże zanim te zmiany nastąpią, oczekiwania wobec tradycyjnego sposobu pełnienia roli płciowej narażają je na przykre konsekwencje. Okazało się, że chłopcy, którzy przejawiali skłonność do nadmiernej dominacji, zgodnie $\mathrm{z}$ tradycyjnym męskim wzorem zachowania, jednocześnie hamowali naturalnie występujący lęk, co sprzyjało u nich zachowaniom ryzykownym oraz antyspołecznym (Radochoński, 1989, s. 247).

W literaturze także możemy znaleźć wiele wyników badań, które pokazują różnice pomiędzy agresją chłopców i dziewcząt, nie tylko w aspekcie nasilenia, ale także pod względem typów zachowania agresywnego. Wyniki badań wskazują, że chłopcy są bardziej agresywni od dziewcząt. Dziewczyny angażują się w bardziej pośrednie formy agresji, zwykle w formie werbalnej, zaś agresja chłopców najczęściej przyjmuje formę agresji fizycznej (Napora, 1998, s. 151). Dziewczynki w wieku 6-10 lat stosują subtelne formy agresji, np. wykluczanie kogoś z grupy rówieśniczej czy określonej aktywności społecznej, rozpowszechnianie plotek, intrygi, drwiny, wyśmiewanie i inne formy dyskryminacji (Napora, 1998, s. 248). Niektórzy są zdania, że przyczyną takiego zjawiska jest przewaga umiejętności werbalnych i percepcyjnych u dziewcząt.

Normy społeczne dotyczące wyrażania złości w formie agresji, zwłaszcza w formie agresji fizycznej, są różne dla kobiet i mężczyzn, dlatego też w procesie wychowania z reguły chłopcy i dziewczynki uczą się różnych reguł okazywania agresji (Wawrzyniak, 2007, s. 65). Chłopcy uczą się bycia „prawdziwymi mężczyznami”, czyli zachowań zorientowanych na ekspansywność i dominację. W tego typu zachowania wpisane są pewne cechy osobowościowe, takie jak: niezależność, pewność siebie, kontrola, zainteresowanie światem zewnętrznym czy słaba kontrola agresji. Natomiast dziewczyny uczą się i internalizują silnie stereotypowe cechy kobiecości, do których zalicza się przede wszystkim: kontrolę agresji, kontrolę autoekspresji, zależność, zainteresowanie domem, wzajemność, brak pewności siebie oraz ekspresję uczuć (Wawrzyniak, 2007, s. 62).

Społeczny wzorzec płci męskiej czy żeńskiej wyznacza określone zachowania, postawy właściwe dla dziewczyn oraz dla chłopców. Socjalizacja agresji w przypadku chłopców sprawia, że preferują oni agresję w formie bezpośredniej, najczęściej fizycznej, co w praktyce oznacza, że dla chłopców typowe są 
bójki, pobicia czy inne formy rozwiązywania konfliktów za pomocą bezpośrednich starć fizycznych (Szczepanik, 2006, s. 56).

Problem agresji występującej w przekazach medialnych, a zwłaszcza wpływ tego zjawiska na dzieci i młodzież, w porównaniu z innymi rodzajami zachowań agresywnych (np. w rodzinie, w szkole) badany jest coraz częściej (Braun-Gałkowska i Ulfik, 200o; Łoś, 2014). Także w społeczeństwie istnieje dość powszechne przekonanie, że wzrost liczby zachowań antyspołecznych, w tym agresji, związany jest z brutalizacją przekazów medialnych (Sarzała, 2009, s. 249).

Ciekawym aspektem, który różnicuje płeć żeńską od męskiej, są zachowania autoagresywne. Dziewczyny częściej niż chłopcy swoją złość czy wrogość w stosunku do otoczenia wyrażają przez działania o charakterze autoagresji - w postaci bulimii, anoreksji, obgryzania paznokci i opuszków palców, samookaleczanie. W tym miejscu należy zaznaczyć, że między zachowaniami autodestruktywnymi uwarunkowanymi kulturą masową a autodestrukcją wywołaną czynnikami chorobowymi granica jest płynna (Szczepanik, 2006, s. 56). Można natomiast postawić hipotezę, że kobiety noszą w sobie potężny ładunek złości, lecz w patriarchalnym społeczeństwie kierują ją do wewnątrz, co powodowuje szereg dolegliwości psychosomatycznych, histerię czy melancholię. Wzrost zachowań agresywnych $\mathrm{w}$ grupie dziewcząt może się wiązać $\mathrm{z}$ odwróceniem wektora złości kierowanej tradycyjnie przeciwko sobie na otoczenie.

Podsumowując powyższe rozważania na temat wpływu tożsamości płciowej na zachowania agresywne dzieci i młodzieży, warto podkreślić, że płeć niewątpliwie je różnicuje, jednak w coraz mniejszym stopniu. Socjalizacja, tolerancja społeczna wobec męskiej agresji, a także liczne stereotypy społeczne na temat płci męskiej i żeńskiej nadal mają duży wpływ nie tylko na skalę agresji u chłopców i dziewcząt, ale również na preferowane przez każdą z płci rodzaje zachowań agresywnych.

\section{Czym zatem może być powodowana „męska agresja” w wykonaniu dziewcząt?}

Interesującego przeglądu teorii wyjaśniających to zjawisko dokonuje Marian Cabalski (2014) w monografii poświęconej przemocy stosowanej przez kobiety. Zestawienie dokonane przez badacza obrazuje proces zmian, które się dokonywały w społecznym rozumieniu tego fenomenu.

Historia naukowego badania przyczyn kobiecej agresji sięga XIX wieku. Wówczas pojawiły się koncepcje mówiące, że typowe zbrodniarki to kobiety o cechach męskich, zarówno w zachowaniu, jak i fizjonomii (Cesare Lomb- 
roso), lub niezaspokojone seksualnie (William Thomas). Początek wieku XX zdominował obraz dyskretnej agresorki, trucicielki i dzieciobójczyni, kobiety fatalnej, podżegającej kochanków do zbrodni, wykreowany przez Ottona Pollaka. Badacz ten jako pierwszy zwrócił uwagę na wpływ cyklu hormonalnego oraz ciąży i menopauzy na zachowania agresywne kobiet. Do dnia dzisiejszego biochemiczne koncepcje przemocy, a zwłaszcza zespół napięcia przedmiesiączkowego - PSM - są przedmiotem żywych dyskusji. W latach 8o. XX wieku sądy w Wielkiej Brytanii zmniejszały odpowiedzialność karną zabójczyń, wskazując PSM jako okoliczność łagodzącą (Cabalski, 2014, s. 151). Rozwój genetyki sprawił, że kobiecej skłonności do agresji zaczęto poszukiwać w materiale genetycznym. Liczne badania nie przyniosły jednoznacznej odpowiedzi w tym zakresie, jakkolwiek u kobiet dopuszczających się przestępstw często obserwowano anomalie w strukturze żeńskich chromosomów płciowych (co oznacza, że kobiety te posiadały cechy męskie). Według Zygmunta Freuda przyczyną kobiecej agresji jest „zazdrość o penisa”, kompleks męskości, który sprawia, że kobiety próbują w swoich postawach i zachowaniach upodobnić się do mężczyzn. Carl Gustav Jung, twórca teorii archetypów, był zdania, że w każdym mężczyźnie jest obecny pierwiastek żeński - anima, zaś w kobiecie pierwiastek męski - animus. W jego opinii agresji dopuszczają się kobiety owładnięte archetypem animusa. Ulegają one maskulinizacji, przejmują od mężczyzn styl bycia, wartości życiowe oraz skłonność do popełniania przemocy. Erik Erikson wiązał kobiecą agresję z przeżywanymi kryzysami rozwojowymi (dojrzewaniem, ciążą, menopauzą), ale również ze wszystkimi radykalnymi zmianami sytuacji życiowej, które oznaczały utratę poczucia bezpieczeństwa. W latach 70. XX wieku Erich Fromm zwrócił uwagę na istnienie agresji obronnej, mającej charakter biologiczny, oraz agresji złośliwej, zdeterminowanej społecznie, będącej pochodną charakteru człowieka. Ta nekrofilityczna postać agresji złośliwej odpowiada, zdaniem Fromma, za upodobanie do niszczenia, pozbawiania życia, do rozrywania na części, rozkładu, zgnilizny. Interesujące jest zestawienie tej obserwacji z kulturowym obrazem cywilizacji śmierci (Cabalski, 2014).

W drugiej połowie XX wieku wzrosło zainteresowanie wpływem czynników społecznych, ekonomicznych i kulturalno-obyczajowych na zmiany w zachowaniu kobiet. Zaczęto spostrzegać agresywne zachowania kobiet jako uwarunkowane przez determinanty społeczne. Kobieca agresja miała być spowodowana biedą, lękiem o życie i zdrowie potomstwa oraz silnym stresem przeżywanym w sytuacjach krytycznych. Za jej wzrost miała odpowiadać także emancypacja, która otworzyła nowe możliwości uaktywnienia się ukrytej kobiecej złości. Interesującą próbę wyjaśnienia przyczyn nasilania 
się kobiecej agresji podjęli kontynuatorzy myśli Emila Durkheima, który był zdania, że skuteczna kontrola zachowań dewiacyjnych jest możliwa tylko wtedy, gdy społeczeństwo charakteryzuje się wewnętrzną spójnością. Zatem w tym wypadku dziewczęcej agresji winny jest stopniowy rozpad tradycyjnych struktur społecznych, relatywizacja norm i wartości, brak mechanizmów skutecznej kontroli (Cabalski, 2014, s. 198).

Zdaniem Cabalskiego zachowania agresywne dziewcząt należy widzieć w perspektywie wieloczynnikowej, gdyż de facto mamy do czynienia ze wzajemnie powiązanymi czynnikami natury biologicznej, psychologicznej, społecznej i kulturowej, które tworzą syndrom sytuacyjny, prowadzący do zachowań o agresywnym, przemocowym charakterze (Cabalski, 2014, s. 200).

Dla lepszego zrozumienia fenomenu eskalacji dziewczęcej agresji warto przywołać pojęcie „pokolenia transformacji”. Od roku 2000 prowadzone są w Polsce pod kierunkiem Rady Monitoringu Społecznego longitudinalne badania nad jakością i warunkami życia społeczeństwa. W edycji z roku 2005 zespół Janusza Czapińskiego odkrył nowe zjawisko społeczne: wykazaną statystycznie kategorię agresywnych nastolatek. Nazwano je „pokoleniem transformacji”, gdyż urodziły się dwa lata przed lub w roku 1989.

Zdecydowanie różniły się od dziewcząt o kilka lat starszych. [...] Znacznie częściej stosowały przemoc fizyczną (biły się między sobą i z chłopcami, wykazywały napastliwe usposobienie do otoczenia, bez zażenowania maltretowały słabszych); ponadto wypijały więcej alkoholu, częściej zażywały narkotyki i wypalały większe ilości papierosów (Cabalski, 2014, s. 259).

Zdaniem badaczy za ten stan rzeczy mogą odpowiadać dwie przyczyny. Po pierwsze, zmiana ustrojowa wywołała niekorzystne przeobrażenia w funkcjonowaniu polskich rodzin - rodzice, zwłaszcza matki „walczyły o przetrwanie” w nowych warunkach ekonomicznych, często kosztem dzieci mających wówczas od kilku miesięcy do trzech lat, czyli w okresie, gdy matka jest najważniejszym obiektem w życiu dziecka. Mogło to także powodować napięcia i konflikty między domownikami oraz wpływać na ogólny klimat rodziny. Po drugie, do wzrostu agresji nastolatek mogła się pośrednio przyczynić reforma oświaty. Powstanie gimnazjów zachwiało dotychczasową hierarchią szkolną. Zamiast przewagi pozycji i doświadczenia dawne siódmo- i ósmoklasistki znalazły się w roli „kotów” wobec starszych koleżanek, które w dawnym systemie byłyby już w liceum. Zespół Czapińskiego twierdzi, że jest to wynik rywalizacji o względy chłopców. Omawiana kategoria nastolatek postanowiła przewyższyć starsze koleżanki w brutalnym stosowaniu przemocy. Dziewczyny atakowały rywalki, ustawiały się z nimi na „solówki”, były wulgarne 
i obsceniczne, koleżanki, z którymi były w konflikcie traktowały jak śmiertelnych wrogów. Marian Cabalski przytacza fragment wywiadu, którego w 2005 roku Janusz Czapiński udzielił „Charakterom”:

Te szesnastolatki są zarażone straszną patologią. [...] one mnie po prostu przeraziły. Są bezwzględne, nietolerancyjne, konserwatywne - w sensie utrwalenia struktury społecznej opartej na hierarchii siły. W ich obrazie świata silniejsi są na górze, słabsi na dole - i niech ci słabsi zginą. Na pytanie, czy wszystkie narody powinny być równe, odpowiadają, że absolutnie nie! Czy wszyscy ludzie zasługują na szacunek? Ich zdaniem: nie! Są lepsi i gorsi (Czapiński za: Krzemionka-Brózda, 2005, s. 264)

Przyczyną tak radykalnej demoralizacji nastolatek mogła być utrata pozycji „starszyzny” szkolnej, a więc traumatyczne doświadczenie degradacji społecznej. Jednak patologiczna zmiana utrwaliła się w kolejnych rocznikach, dla których gimnazjum było już naturalną częścią systemu, trudno więc mówić o kryzysie utraty. Ponadto podobne zjawisko zostało zaobserwowane kilka lat wcześniej w wielu krajach Europy Zachodniej, które nie doświadczyły ani transformacji ustrojowej, ani reformy systemu oświaty. Przypuszczam, że jest to efekt trendów kulturowych o znacznie głębszych uwarunkowaniach i większym zasięgu, związanych $\mathrm{z}$ interpretacją ról płciowych i miejscem kobiety we współczesnym społeczeństwie.

$\mathrm{Na}$ zakończenie chciałabym przywołać jeszcze jedną teorię. Katarzyna Stadnik, współautorka książki Anielice czy diablice? Dziewczęta w szponach seksualizacji $i$ agresji $w$ perspektywie socjologicznej, pisze o agresywnych zachowaniach dziewcząt, porównując sytuację, w której są na co dzień nastolatki, do ula (Stadnik i Wójtewicz, 2016). Wśród dziewcząt panuje pszczela hierarchia. Królowa jest tylko jedna - to dziewczyna o najwyższej pozycji w grupie. Ma zwolenniczki, to jej najbliższe otoczenie, są też szeregowe robotnice. Królowa musi być bezwzględna, bo zawsze może zostać zdetronizowana (a nawet stracić głowę). Osoba, która postanawia zająć miejsce królowej, także musi być bezwzględna. Ich konflikt może przybierać drastyczne formy. Królowa, czyli dziewczyna uważana za najładniejszą, najpopularniejszą i najatrakcyjniejszą wśród chłopców, będzie się bronić przy pomocy swoich zwolenniczek, nie przebierając w środkach. Życie współczesnych nastolatek przypomina grę o tron.

Ten obrazek, żywcem wyjęty z amerykańskiego serialu dla młodzieży, nie tyle opisuje złożoną rzeczywistość świata dojrzewających kobiet, ile kształtuje wyobrażenia na temat tego, jak wyglądają relacje między nastolatkami, co należy do kanonu zachowań i co powinno być główną ambicją i celem każdej dziewczyny. W tym wypadku mamy do czynienia nie z rozpoznaniem 
ukrytej struktury, lecz $\mathrm{w}$ znacznie większym stopniu $\mathrm{z}$ modelowaniem zachowań. W ramach „modelu ula” dokonuje się skanalizowanie dziewczęcej agresji i zredukowanie jej do rywalizacji o chłopców. W tej sytuacji dojrzewające kobiety, walcząc między sobą, nie doświadczają różnorodności aspektów własnej siły i nie angażują jej w innych obszarach życia społecznego.

Pytanie, jak nauczyć nastolatki konstruktywnie zarządzać uwolnioną złością i kontrolować wybuchy agresji, zanim „żeńskie tsunami” doprowadzi do zagłady świata takiego, jakim go znamy, nadal pozostaje otwarte.

\section{BIBLIOGRAFIA}

Braun-Gałkowska, M., Ulfik, I. (200o). Zabawa w zabijanie. Oddziaływanie przemocy prezentowanej w mediach na psychikę dzieci. Warszawa: Wydawnictwo Krupski i S-ka.

Cabalski, M. (2014). Przemoc stosowana przez kobiety. Kraków: Oficyna Wydawnicza Impuls.

Hüther, G., Hauser, U. (2014). Wszystkie dzieci sq zdolne. Jak marnujemy wrodzone talenty. Słupsk: Dobra Literatura.

Krzemionka-Brózda, D. (2005). Pokolenie transformacji - żeńskie tsunami. Charaktery, 12.

Kulik, A., Grądziel, J., Pieńkoś, M. (2016). Psychospołeczne uwarunkowania radzenia sobie z gniewem u dziewcząt. W: W. Poleszak (red.), Wyzwania i zagrożenia adolescencji. Lublin: Innovatio Press Wydawnictwo Naukowe.

Łoś, M. (2014). Skutki poziomu ekspozycji dzieci i młodzieży na przemoc w mediach oraz propozycje działań profilaktycznych. Pozyskano z: https://depot.ceon.pl/bitstream/handle/123456789/15138/skutki\%2opoziomu.pdf?sequence=1, [data dostępu: 15.05.2020].

Misiewicz, M. (2007). Poczucie własnej wartości u młodzieży. Warszawa: WSiP.

Napierała, M. (2012). Filozofia reklamy; historia, psychologia, techniki. Kraków: Wydawnictwo Petrus.

Napora, E. (1998). Agresja a zmienne osobowe i społeczne u młodych ludzi. W: Agresja i przemoc we wspótczesnym świecie (t. 1). Kraków: Oficyna Wydawnicza Impuls.

Obuchowski, K. (2002). Psychologia dążeń ludzkich. Warszawa: WSiP.

Piotrowska, J., Synakiewicz, A. (2010). Dlaczego dziewczęta sq agresywne. Pozyskano z: https:// www.monitor.edu.pl/analizy/dlaczego-dziewczeta-sa-agresywne-szkoła wobec problemu przemocy ze względu na płeć, [data dostępu: 12.04.2019].

Poraj, G. (2006). Szkoła chora na agresję. Psychologia w Szkole, 3, 87-99.

Radochoński, M. (2008). Tożsamość płciowa a zachowania agresywne młodzieży. W: Z. Bartkowiak, A. Węgliński (red.), Skuteczna resocjalizacja. Doświadczenia i propozycje. Lublin: Wydawnictwo UMCS.

Samujło, A. (1998). Uwarunkowania zachowań agresywnych dzieci i młodzieży w środowisku szkolnym. W: Agresja i przemoc we wspótczesnym świecie (t. 1). Lublin: Wydawnictwo UMCS.

Sarzała, D. (2009). Problem agresji i przemocy w multimediach elektronicznych - aspekty psychologiczne i etyczne. W: J. Bednarek, A. Andrzejewska (red.), Cyberświat-możliwości i zagrożenia. Warszawa: Wydawnictwo Akademickie Żak.

Stadnik, K., Wójtewicz, A. (2016). Anielice czy diablice? Dziewczęta w szponach seksualizacji i agresji w perspektywie socjologicznej. Sulejówek: Wydawnictwa Akademickie i Profesjonalne.

Szczepanik, R. (2006). Płeć jako zmienna różnicująca orzeczenie stopnia demoralizacji nieletnich dziewcząt i chłopców. W: Role płciowe. Socjalizacja i rozwój. Łódź: Wydawnictwo Uniwersytetu Łódzkiego.

Turner, J.S., Helms, D.B. (2006). Rozwój człowieka. Warszawa: WSiP. 
Urban, B. (2012). Agresja młodzieży i odrzucenie rówieśnicze. Warszawa: Wydawnictwo Naukowe PWN.

Wawrzyniak, J. (red.). (2007). Socjologiczne i psychopedagogiczne aspekty przemocy. Łódź: Wydawnictwo Wyższej Szkoły Humanistyczno-Ekonomicznej w Łodzi.

Winczewska, B. (2019). Procedura postępowania w przypadku agresji ucznia do nauczyciela. Pozyskano z: https://www.portaloswiatowy.pl/bezpieczenstwo-w-szkole/procedura-postepowania-w-przypadku-agresji-ucznia-wobec-nauczyciela-979o.html, [data dostępu: 17.04.2019].

Wojnarska, A. (2008). Kompetencje społeczne a agresywność uczniów szkół gimnazjalnych. W: Z. Bartkowicz, A. Węgliński (red.), Skuteczna resocjalizacja. Doświadczenia i propozycje. Lublin: Wydawnictwo UMCS.

Żebrowska M. (red.). (1994). Psychologia rozwojowa dzieci i młodzieży. Warszawa: Wydawnictwo Naukowe PWN.

\section{SUMMARY}

\section{Young and furious. \\ Searching for sources of teenage girls aggression}

For the last 20 years, the tendency to violent behaviours among young girls increased significantly. This article describes the importance of puberty, peer group, family and school environment influence in generating aggression. The differences in motives and forms of aggressive behaviour between teenage girls and boys are presented, together with selected concepts explaining root causes of women aggression.

KEYWORDS: teenage girls, aggression, raising, education, culture 